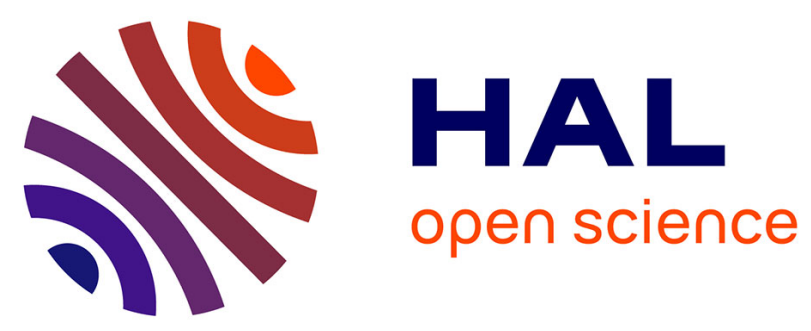

\title{
Dose-dense therapy improves survival in aggressive non-Hodgkin's lymphoma
}

\author{
Michael A. Fridrik, Hubert Hausmaninger, Alois Lang, Johannes Drach, Otto \\ Krieger, Dietmar Geissler, Gerhard Michlmayr, Ernst Ulsperger, Andreas \\ Chott, Wilhelm Oberaigner, et al.
}

\section{To cite this version:}

Michael A. Fridrik, Hubert Hausmaninger, Alois Lang, Johannes Drach, Otto Krieger, et al.. Dosedense therapy improves survival in aggressive non-Hodgkin's lymphoma. Annals of Hematology, 2009, 89 (3), pp.273-282. 10.1007/s00277-009-0811-x . hal-00535085

\section{HAL Id: hal-00535085 \\ https://hal.science/hal-00535085}

Submitted on 11 Nov 2010

HAL is a multi-disciplinary open access archive for the deposit and dissemination of scientific research documents, whether they are published or not. The documents may come from teaching and research institutions in France or abroad, or from public or private research centers.
L'archive ouverte pluridisciplinaire HAL, est destinée au dépôt et à la diffusion de documents scientifiques de niveau recherche, publiés ou non, émanant des établissements d'enseignement et de recherche français ou étrangers, des laboratoires publics ou privés. 


\title{
Dose-dense therapy improves survival in aggressive non-Hodgkin's lymphoma
}

\author{
Michael A. Fridrik • Hubert Hausmaninger • Alois Lang • Johannes Drach • \\ Otto Krieger • Dietmar Geissler • Gerhard Michlmayr • Ernst Ulsperger • \\ Andreas Chott • Wilhelm Oberaigner • Richard Greil
}

Received: 1 June 2008 / Accepted: 5 August 2009/Published online: 20 August 2009

(C) Springer-Verlag 2009

\begin{abstract}
This study aimed to determine whether dosedense therapy improves 3-year survival over the standard therapy for untreated aggressive lymphoma. One hundred and fifteen patients with untreated aggressive lymphoma were stratified by center, age, and international prognostic index and randomized to one of two treatment arms. One hundred and three were eligible. The experimental dosedense arm consisted of weekly therapy with cyclophosphamide, epirubicine, vincristine, prednisolone, ifosfamide, etoposide, methotrexate, dexamethasone, and filgrastim
\end{abstract}

Partly presented in the 39th Meeting of the American Society of Clinical Oncology, Chicago.

ClinicalTrials.gov registration no. NCT00517894

M. A. Fridrik $(\bowtie)$

Department Internal Medicine 3, Centre for Hematology

and Medical Oncology, General Hospital Linz,

Krankenhausstrasse 9,

4020 Linz, Austria

e-mail: michael.fridrik@akh.linz.at

H. Hausmaninger $\cdot$ R. Greil

Department Medicine, University Salzburg,

Salzburg, Austria

A. Lang

Department Medicine LKH,

Feldkirch, Austria

J. Drach

Internal Department 1, University Vienna,

Vienna, Austria

O. Krieger

Department Internal Medicine 1, Kh-Elisabethinen,

Linz, Austria
(CEOP/IMVP-Dexa). The standard arm consisted of threeweekly cyclophosphamide, doxorubicin, vincristine, and prednisolone (CHOP). The primary endpoint was overall survival after 3 years. Overall survival at 3 years was 0.766 $(95 \%$ CI $0.6247,0.8598)$ in the dose-dense arm and 0.462 (95\% CI $0.3200,0.5925)$ in the CHOP arm. Overall 5-year survival was $0.746(95 \%$ CI $0.603,0.843)$ in the dose dense and 0.406 (95\% CI $0.265,0.543)$ in the CHOP arm $(P=0.0062)$. Grade 3 and 4 infections occurred four times more frequently in the dose-dense arm. However, two

D. Geissler

Department Medicine LKH,

Klagenfurt, Austria

G. Michlmayr

Department Medicine 1, Kh Bh Schwestern,

Linz, Austria

E. Ulsperger

Department Medicine Kh,

Lainz, Austria

A. Chott

Department Pathology, University Vienna,

Vienna, Austria

W. Oberaigner

Institute for Clinical Epidemiology of the TILAK, Innsbruck, Austria 
patients died from toxicity in the dose-dense arm and three in the CHOP arm. Dose-dense therapy with CEOP/IMVPDexa is feasible and resulted in an absolute increase of $34 \%$ in the survival probability compared to CHOP in untreated patients with aggressive lymphoma.

Keywords Aggressive non Hodgkin lymphoma . Treatment · Dose-dense · Diffuse large B-cell lymphoma

\section{Introduction}

The cyclophosphamide, doxorubicin, vincristine, and prednisolone (CHOP) polychemotherapy regimen was the first therapy to cure aggressive non-Hodgkin's lymphoma [7]. With this therapy, the overall survival of patients is $52 \%$ at short-term follow-up, but long-term remissions occur in less than $30 \%$ of patients $[9,17]$. Therefore, more efficient therapies are urgently needed.

Several treatment regimens using more than four drugs, based on the Goldie-Coldman hypothesis [13] of using more effective drugs early in treatment to avoid resistance, improved survival when tested in single-center, phase II studies. However, in randomized trials, these regimens proved to be more toxic than CHOP [8]. Problems with patient selection may be the major reason why these newer regimens had inferior outcome in the randomized trial despite promising results in the phase II trials. Additionally, increasing the number of drugs in a treatment regimen usually results in a dose reduction of the key drugs cyclophosphamide and anthracycline. This may also explain the failure of these newer regimens.

The concept of dose density is the application of cytotoxic drugs in short intervals to target the malignant cells during the phase of rapid regrowth after the last treatment. The cyclophosphamide, epirubicine, vincristine, prednisolone, ifosfamide, etoposide, methotrexate, dexamethasone, and filgrastim (CEOP/IMVP-Dexa) is a dose-dense regimen, with weekly administration of cytotoxic drugs. The dose of anthracyline and cyclophosphamide was not reduced compared to CHOP. To avoid excessive myelotoxicity, we alternated myelotoxic and less myelotoxic drugs and used prophylactic filgrastim. The regimen proved to be safe and effective in earlier trials of the Austrian Working Party for Medical Tumor Therapy (AGMT) with an overall survival of 0.583 after 8 years [11]. In this study, we tested the hypothesis that dose-dense therapy results in better survival than $\mathrm{CHOP}$ in patients with untreated aggressive lymphoma.

Patients and methods

This study (NHL-5) was a prospective, multicenter, randomized phase III study of the AGMT. The study was reviewed by the ethics committees at each participating institution and was performed according to the Declaration of Helsinki. Central randomization was done using by a computer method; patients were stratified by center, international prognostic index (IPI) [1], and age. All patients gave written informed consent before entry.

The primary endpoint was survival after 3 years. The secondary endpoints were survival after 5 years, time to treatment failure after 3 and 5 years, remission rate, and toxicity.

Between February 1995 and September 2001, 115 patients were randomized. Patients between 18 and 70 years of age and with centrally reviewed, histologically confirmed diffuse large B cell, anaplastic large-cell lymphoma, or peripheral $\mathrm{T}$ cell lymphoma unspecified, measurable disease, in all stages, were included in the study. Patients with lymphoblastic or Burkitt histology, CNS disease, HIV-positive patients, pregnant or lactating women, pretreatment, other malignancy, or concomitant diseases that precluded chemotherapy were excluded from the study.

\section{Treatment}

The dose-dense therapy (CEOP/IMVP-Dexa) was provided as previously described $[10,12]$. Briefly, cyclophosphamide $\left(750 \mathrm{mg} / \mathrm{m}^{2}\right.$ i.v. day 1$)$, epirubicine $\left(70 \mathrm{mg} / \mathrm{m}^{2}\right.$ i.v. day 1$)$, vincristine $\left(1.4 \mathrm{mg} / \mathrm{m}^{2}\right.$ i.v. day $\left.1+8\right)$, prednisolone $(100 \mathrm{mg}$ p.o. days 1-5), ifosfamide $\left(2,000 \mathrm{mg} / \mathrm{m}^{2}\right.$ i.v. days 15-17), etoposide $\left(100 \mathrm{mg} / \mathrm{m}^{2}\right.$ i.v. days $\left.15-17\right)$, dexamethasone (40 mg p.o. or i.v. days 15-19), and methotrexate $\left(800 \mathrm{mg} / \mathrm{m}^{2}\right.$ i.v. day 22) were used. Mesna uroprotection was given after ifosfamide and calcium folinate rescue after methotrexate. Filgrastim was given on days 2-7, 9-12, 18-21, and 23-28. Chemotherapy doses were maintained unless neutrophil counts fell below $1.0 \mathrm{G} / \mathrm{L}$. If neutrophil counts fell between 1.0 and $0.2 \mathrm{G} / \mathrm{L}$, doses were reduced to $50 \%$. If neutrophil counts were $0.2 \mathrm{G} / \mathrm{L}$ or lower, chemotherapy was delayed for 1 week. In patients with infections, chemotherapy was delayed until recovery. Antibiotic prophylaxis was not used. Patients 60 years of age or older had a $20 \%$ dose reduction for all cytostatic drugs.

In the experimental dose-dense arm, two to four cycles of CEOP/IMVP-Dexa was given to reach a complete remission (CR). Patients who did not achieve a partial remission (PR) after two cycles or a CR after four cycles were removed from the study and treated at the discretion of the treating physician. Patients achieving a CR received two consolidation cycles after achieving the CR (Fig. 1)

In the standard arm, three-weekly CHOP was given as described earlier [7]. Three to six cycles were given to reach a CR. Patients who did not reach a PR after three cycles or a $\mathrm{CR}$ after six cycles were removed from the 
Fig. 1 Treatment plan

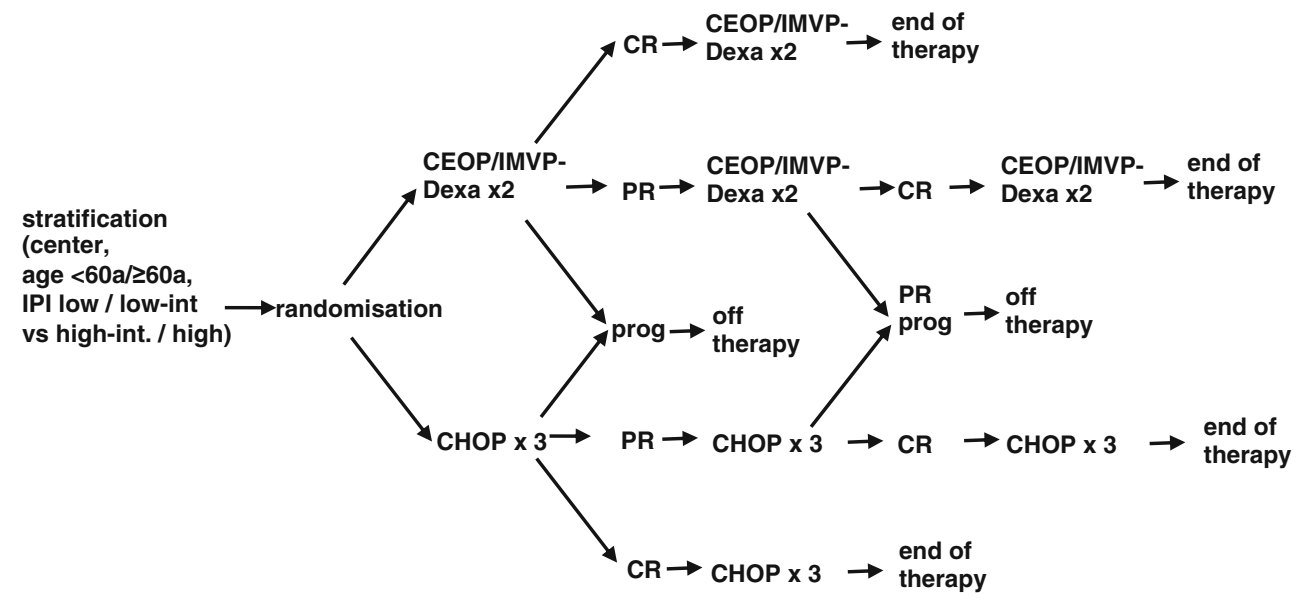

study and treated at the discretion of the treating physician. Patients achieving a CR received three consolidation cycles after achieving the CR (Fig. 1). The number of treatment cycles depended on how quickly the patient responded to the treatment. In patients with one to five cycles in the $\mathrm{CHOP}$ arm or one to three cycles in the dose-dense arm the treatment was stopped because of progression, toxicity, or early death (Figs. 1 and 2).

\section{Biostatistics}

All eligible patients were included in the analysis. Survival estimates were obtained by the Kaplan-Meier method [16]. The log-rank test was used to compare survival between the two arms. Unadjusted hazard ratios were estimated by the COX regression [6]. The patient characteristics, side effects, and remission rates were compared using the $t$ test,
Fig. 2 Flow sheet of patients and number of cycles received

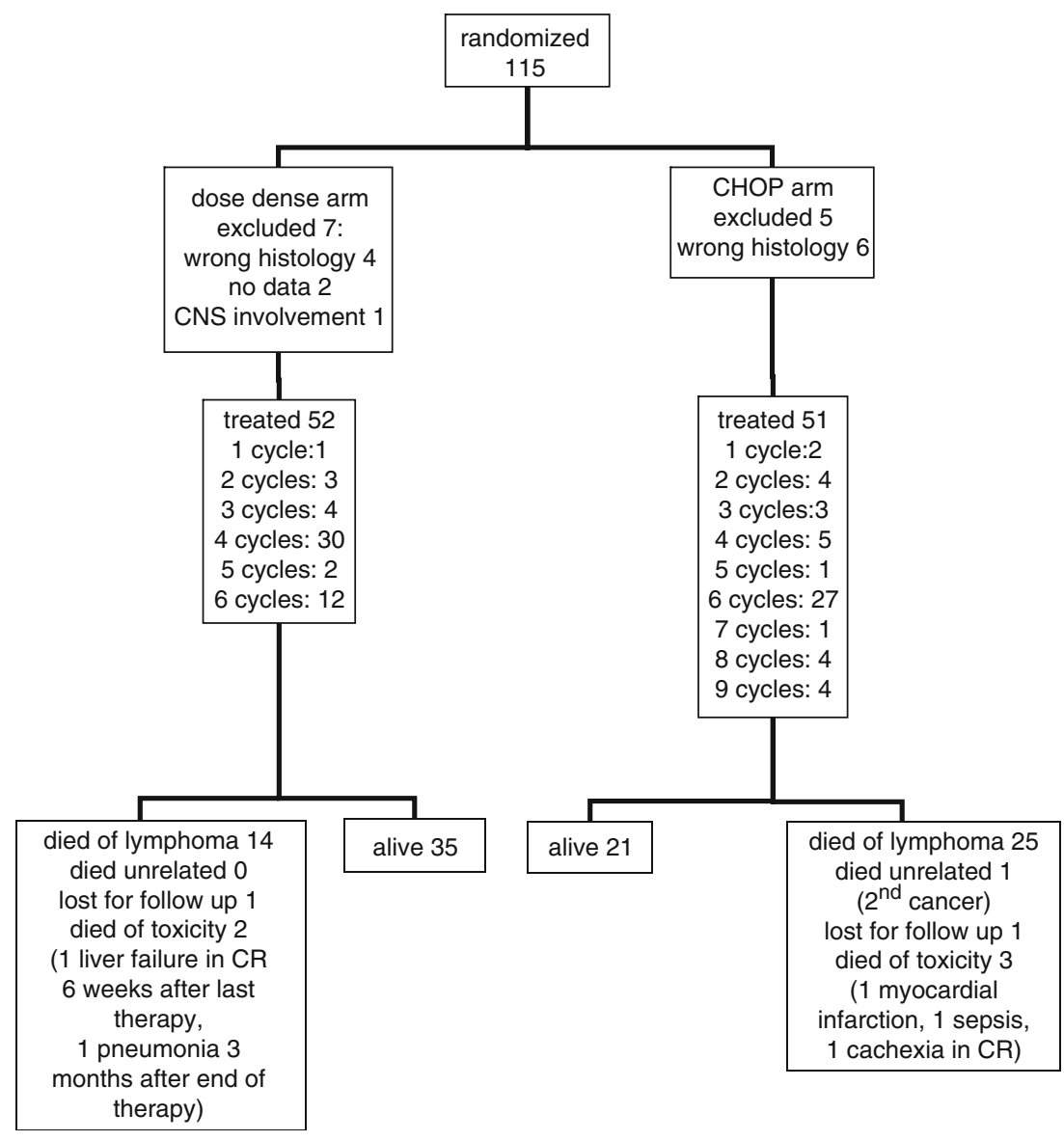


the parameter-free test, or the Pearson chi-square test, where appropriate.

To detect an estimated improvement in the 3-year survival from 0.54 to 0.72 with a power of $80 \%$ and an alpha-error of 0.05 in a one-sided test, at least 50 patients per study arm were required. We chose a one-sided test because we were only interested in determining if dosedense therapy was better than CHOP.

$\mathrm{CR}$, complete remission undetermined $(\mathrm{CRu}), \mathrm{PR}$, no change, progression, time to relapse, and time to treatment failure (TTF) were defined according to Cheson et al. [4]. Thus, survival includes all eligible patients and counts all deaths as events. TTF is the time from registration until relapse, progression, toxic death, withdrawal, or date last known to be alive, excluding deaths from unrelated causes.

\section{Toxicity}

Toxicity was assessed before each chemotherapy dose and whenever the patient visited the outpatient clinic using the WHO toxicity criteria (http://www.fda.gov/cder/cancer/ toxicityframe.htm). Patients randomized to the dosedense arm had weekly visits, while those in the CHOP arm were seen at 3-week intervals. In order to avoid differences resulting from the different evaluation intervals in the two arms, only the most severe toxicity during the whole therapy was considered.

\section{Results}

\section{Patients}

Between February 1995 and September 2001, 115 patients were enrolled; 52 were randomized into the dose-dense arm, and 51 were randomized into the CHOP arm. Seven patients were excluded from the dose-dense arm and five from the CHOP arm. Most of the exclusions were due to histology. In the dose-dense arm, two patients were excluded because no data were received from the treatment center, and one was excluded due to CNS involvement at diagnosis (Fig. 2). The patient characteristics were comparable in both arms (Table 1). The median observation time for surviving patients was 62.5 months.

\section{Survival and treatment after relapse}

Dose-dense therapy was advantageous in terms of overall survival. Overall survival at 3 years was $0.766(95 \% \mathrm{CI}$ $0.6247,0.8598)$ in the dose-dense arm and $0.462(95 \% \mathrm{CI}$ $0.3200,0.5925)$ in the CHOP arm. Overall survival at 5 years was $0.746(95 \% \mathrm{CI}, 0.603,0.843)$ in the dose-dense arm and 0.406 (95\% CI, 0.265, 0.543) in the CHOP arm. This latter difference was statistically significant with a $P$ value of 0.0062 (Fig. 3). The 5-year TTF was 0.5516 $(95 \%$ CI $0.4060,0.6752)$ in the dose-dense arm and 0.4119 (95\% CI 0.2697-0.5486) in the CHOP arm (Fig. 4). This difference almost reached the level of statistical significance $(P=0.0564)$. Five-year overall survival for patients with low or low-intermediate IPI was $0.8471(95 \% \mathrm{CI}$ $0.6908,0.9283)$ in the dose-dense and $0.5364(95 \%$ CI $0.3621,0.6852$ ) in the CHOP arm, respectively (Fig. 5). For patients with high or high-intermediate IPI, 5-year overall survival was $0.4167(95 \%$ CI $0.1525,0.6653)$ in the dosedense arm and 0.0769 (95\% CI $0.0048,0.2920)$ in the $\mathrm{CHOP}$ arm. For the patients in the low or low-intermediate IPI risk group, this difference was statistically significant different with a $P$ value of 0.0219 (Fig. 5).

In the CHOP arm, a few more $\mathrm{T}$ cell lymphomas, primarily anaplastic large-cell lymphoma, were included. This difference was not statistically significant (Table 1). Because $\mathrm{T}$ cell lymphomas have a less favorable outcome than B cell lymphomas, we also analyzed our data when $T$ cell lymphomas were excluded, but the survival benefit remained. In the dose-dense arm, one of the two patients with peripheral $\mathrm{T}$ cell lymphoma and one of the two patients with anaplastic large-cell lymphoma relapsed and
Table 1 Patients characteristics

IPI international prognostic index, $l-i$ low-intermediate, $h-i$ high-intermediate, $D L B C L$ diffuse large B cell lymphoma, $A L C L$ anaplastic large-cell lymphoma, $P T L-U$ peripheral $\mathrm{T}$ cell lymphoma unspecified

\begin{tabular}{llll}
\hline & Dose-dense arm & CHOP arm & $P$ value \\
\hline Male/female, $n(\%)$ & $26(50 \%) / 26(50 \%)$ & $31 / 20$ & 0.271 \\
Age (median years) & 47 & 46 & 0.092 \\
Age (range years) & $20-69$ & $18-68$ & \\
Age $>60$ years & $11(21.2 \%)$ & $9(17.6 \%)$ & 0.653 \\
IPI low/l-i & $28(53.8 \%) / 12(23.1 \%)$ & $24(47.1 \%) / 14(27.5 \%)$ & 0.909 \\
IPI h-i/high & $5(9.6 \%) / 7(13.5 \%)$ & $6(11.8 \%) / 7(13.7 \%)$ & \\
DLBCL & 46 & 38 & 0.2157 \\
ALCL & 2 & 6 & \\
PTL-U & 2 & 5 & \\
Unclassified & 2 & 2 & \\
\hline
\end{tabular}




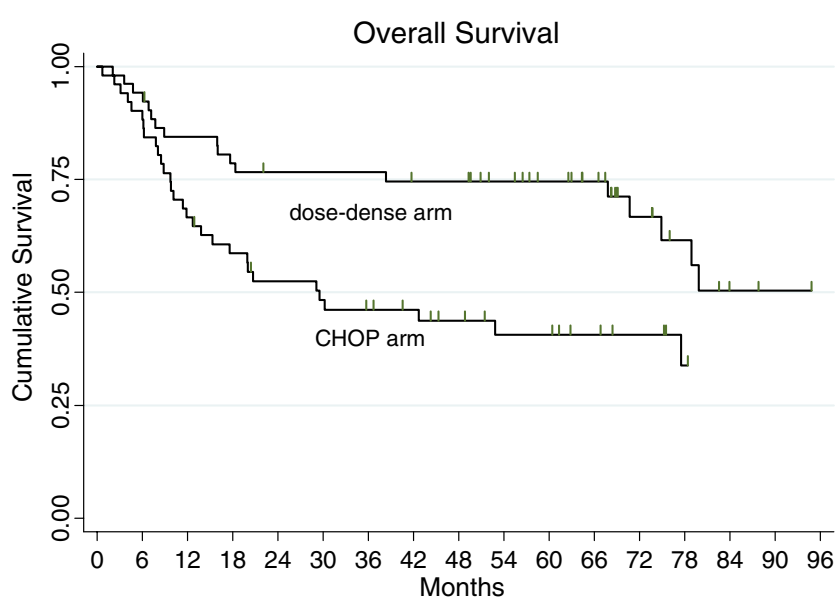

Fig. 3 Overall survival (log-rank test: $P=0.0062$ ) after 5 years $P=0.00034359$, after 6 years $P=0.0138098$, and after 7 years $P=0.211773823$

subsequently died. In the CHOP arm, three of the six patients with peripheral $\mathrm{T}$ cell lymphoma and three of the six patients with anaplastic large-cell lymphoma relapsed and subsequently died (Table 4). When analyzing the subgroups, the patient numbers get smaller and results are less robust. However, it seems to be unlikely that the small number patients that died from relapsed $\mathrm{T}$ cell lymphoma explains the survival benefit of the dose-dense therapy.

In the case of relapse, two patients in the dose-dense arm and five patients in the CHOP arm received stem-cell transplants. Rituximab was a part of the salvage treatment in two patients in the dose-dense arm and in one patient in the CHOP arm.

\section{Response}

The overall remission rate was $94.2 \%(49 / 52)$ and $86.3 \%$ $(44 / 51)$ in the dose-dense and the CHOP arm, respectively. A CR was achieved in $39(75 \%)$ patients and a CRu in four

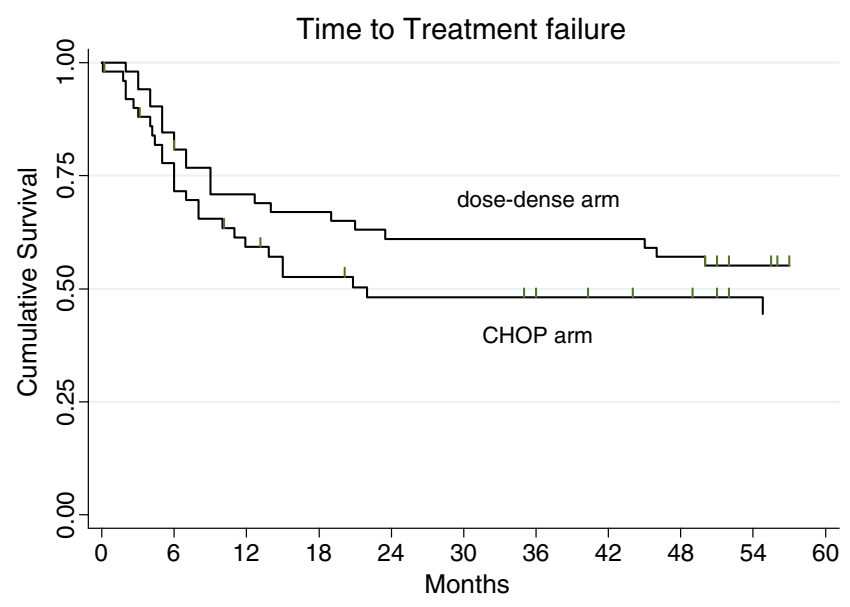

Fig. 4 Time to treatment failure (log-rank test: $P=0.0564)$

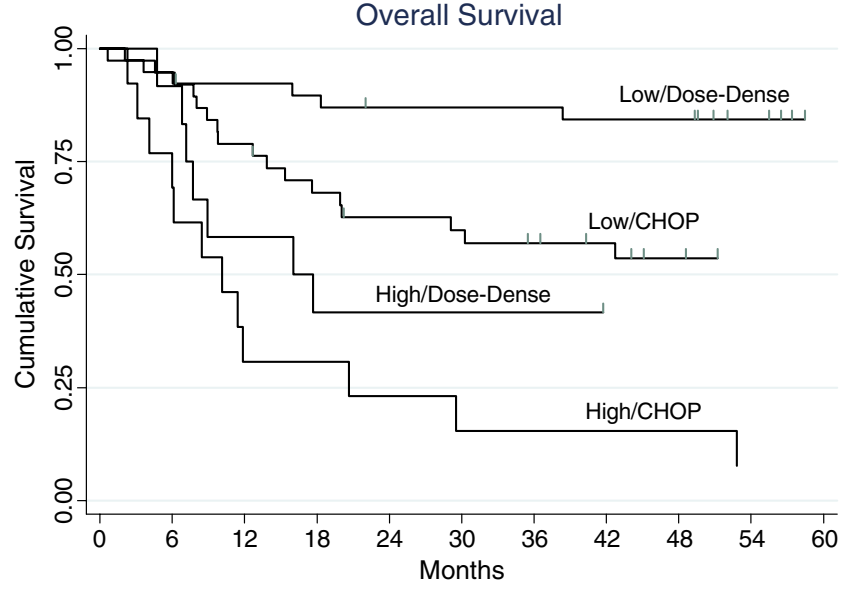

Fig. 5 Overall survival according to IPI. Low low and lowintermediate IPI, High high and high-intermediate IPI. $P=0.0219$ for low-dose dense vs. low CHOP. $P=0.148$ for high-dose dense vs. high CHOP

(7.7\%) patients in the dose-dense arm. In the CHOP arm, 37 (72.5\%) patients had a CR and none had a CRu. Only two patients $(3.8 \%)$ progressed during therapy in the dosedense arm and seven $(13.7 \%)$ in the CHOP arm. These differences did not reach statistical significance. One patient died in the dose-dense arm before an evaluation of the remission was possible.

\section{Dose intensity}

The planned and received chemotherapy doses for both arms are listed in Table 2. The planned dose intensity for vincristine and the anthracyclines were comparable in both arms. The cyclophosphamide dose was higher in the CHOP arm, but ifosfamide was added to the dose-dense arm to compensate. In addition, etoposide and methotrexate were given in the dose-dense arm. The received dose intensity was somewhat lower than the planned dose intensity in the dose-dense arm.

\section{Toxicity}

Dose-dense therapy produced significantly more toxicity than standard therapy. Table 3 lists the side effects that were significantly different between the two arms. Because the blood samples were taken at different intervals (at least weekly intervals in the dose-dense arm and at least threeweekly intervals in the CHOP arm), the most severe toxicity for each treatment cycle was documented. Laboratory-documented toxicity, particularly hematologic toxicity, was higher in the dose-dense arm. In the dosedense arm, long-term peripheral neuropathy grades 1 and 2 were reported in three and two patients, respectively, lasting up to 3 years after the end of therapy. Myelodysplastic 
Table 2 Planned dose intensity (DI) and percentage of received dose of planned dose

CI confidence intervals

\begin{tabular}{|c|c|c|c|c|}
\hline \multirow[t]{2}{*}{ Drug } & \multicolumn{2}{|c|}{ Planned DI, $\mathrm{mg} / \mathrm{m}^{2} /$ day } & \multicolumn{2}{|c|}{ Median received dose, $\%(95 \% \mathrm{CI})$} \\
\hline & Dose-dense arm & CHOP arm & Dose-dense arm & $\mathrm{CHOP}$ arm \\
\hline Cyclophosphamide & 26.79 & 35.710 & $83.03(80.78-85.28)$ & $94.59(93.09-96.09)$ \\
\hline Epirubicine/doxorubicin & 2.50 & 2.380 & $82.52(80.25-84.80)$ & $95.21(93.70-96.71)$ \\
\hline Vincristine & 0.10 & 0.095 & $60.60(57.23-63.96)$ & $92.06(89.30-94.82)$ \\
\hline Prednisone & 3.57 & 4.760 & $81.29(78.47-84.11)$ & $96.66(92.40-100.9)$ \\
\hline Ifosfamide & 214.29 & & $80.49(77.32-83.65)$ & \\
\hline Etoposide & 10.72 & & $79.57(76.30-82.84)$ & \\
\hline Dexamethasone & 7.14 & & $79.05(75.37-82.74)$ & \\
\hline Methotrexate & 28.57 & & $73.64(69.79-77.50)$ & \\
\hline
\end{tabular}

syndromes or leukemias were not observed to date. Two deaths due to toxicity occurred in the dose-dense arm. One patient died in CR at home, 6 weeks after the last therapy, from liver failure of unknown cause. Another patient died from pneumonia without neutropenia, 3 months after the last chemotherapy. In the CHOP arm, we observed three deaths due to toxicity, one due to sepsis and another due to myocardial infarction while on treatment. One patient died in CR because of cachexia after treatment (Fig. 2). Dosedense therapy with CEOP-IMVP-Dexa can be given as an outpatient regimen. However, most patients were hospitalized on days $15-17$ and $22-24$ of treatment. With this regimen, clinic visits on days $1,8,15-17$, and 22-24 are necessary. CHOP regimen requires only one visit every 3 weeks. Although the cost of treatment was not an endpoint of our study, the more frequent clinic visits and larger number of drugs make the dose-dense therapy more costly than CHOP.
Treatment after relapse

Nineteen patients relapsed or progressed after a median of 64 weeks (range 9-217 weeks) in the dose-dense arm. Twelve of these 19 patients died of lymphoma after a median of 45 weeks (range 0-220 weeks) after relapse. Six patients are still alive after $137+$ to $333+$ weeks. Twentyfive patients relapsed or progressed after a median of 44 weeks (range 2-237 weeks) in the CHOP arm. All these patients died of lymphoma after a median of 45 weeks (range 2-214 weeks) after relapse. In the dose-dense arm, two patients received CEOP/IMVP as salvage treatment, three received $\mathrm{CHOP}$, and 10 received other salvage chemotherapy regimens. Two were treated with a rituximab-containing regimen, and two received autologous stem-cell transplants. In the CHOP arm, three patients received salvage treatment with CEOP/IMVP, one with $\mathrm{CHOP}$, and 19 with other regimens. One patient received

Table 3 Side effects: worst toxicity per patient according to WHO toxicity criteria listed as grade 0 (never had any toxicity), grade 3 , and grade 4

\begin{tabular}{|c|c|c|c|c|c|c|c|}
\hline \multirow[t]{2}{*}{ Toxicity } & \multicolumn{3}{|l|}{ Dose-dense arm } & \multicolumn{3}{|l|}{ CHOP arm } & \multirow[t]{2}{*}{$P$} \\
\hline & $\begin{array}{l}\text { WHO grade } 0 \\
(\%)\end{array}$ & $\begin{array}{l}\text { WHO grade } 3 \\
(\%)\end{array}$ & $\begin{array}{l}\text { WHO grade } 4 \\
(\%)\end{array}$ & $\begin{array}{l}\text { WHO grade } 0 \\
(\%)\end{array}$ & $\begin{array}{l}\text { WHO grade } 3 \\
(\%)\end{array}$ & $\begin{array}{l}\text { WHO grade } 4 \\
(\%)\end{array}$ & \\
\hline Hemoglobin & 0.0 & 39.2 & 7.8 & 56.0 & 4.0 & 2.0 & $<0.001$ \\
\hline Neutrophil count & 7.8 & 11.8 & 58.8 & 34.0 & 20.0 & 20.0 & 0.001 \\
\hline Platelet count & 37.3 & 9.8 & 17.6 & 78.0 & 4.0 & 2.0 & 0.001 \\
\hline Stomatitis & 13.7 & 27.5 & 2.0 & 66.0 & 0.0 & 0.0 & $<0.001$ \\
\hline Nausea/vomiting & 25.5 & 29.4 & 5.9 & 52.0 & 12.0 & 6.0 & 0.031 \\
\hline Fever & 56.9 & 2.0 & 0.0 & 86.0 & 0.0 & 0 & $<0.001$ \\
\hline Infection & 9.8 & 25.5 & 7.8 & 50.0 & 6.0 & 2.0 & $<0.001$ \\
\hline Hair loss & 2.0 & 94.1 & 0.0 & 6.0 & 74.0 & 0.0 & 0.046 \\
\hline Skin & 64.7 & 3.9 & 0.0 & 94.0 & 0.0 & 0.0 & 0.004 \\
\hline Neurotoxicity & 13.7 & 11.8 & 3.9 & 56.0 & 4.0 & 0.0 & $<0.001$ \\
\hline
\end{tabular}

$P$ Pearson chi-square test 
Table 4 Outcome of relapsed patients

\begin{tabular}{|c|c|c|c|c|c|c|}
\hline $\begin{array}{l}\text { Patient } \\
\text { no. }\end{array}$ & $\begin{array}{l}\text { Randomization } \\
\text { arm }\end{array}$ & $\begin{array}{l}\text { Remission to } 1 \text { st line } \\
\text { therapy }\end{array}$ & $\begin{array}{l}\text { Weeks from } \\
\text { randomization } \\
\text { to relapse }\end{array}$ & $\begin{array}{l}\text { Weeks from relapse to death } \\
\text { or last FU }\end{array}$ & $\begin{array}{l}\text { Relapse } \\
\text { therapy }\end{array}$ & Histology \\
\hline 18 & $\mathrm{CHOP}$ & Prog & 8 & 29 & CEOP/IMVP & ALCL \\
\hline 105 & $\mathrm{CHOP}$ & $\mathrm{CR}$ & 51 & 36 & CEOP/IMVP & $\mathrm{PB}$ \\
\hline 54 & $\mathrm{CHOP}$ & PR & 31 & 63 & CEOP/IMVP & DLBCL \\
\hline 68 & $\mathrm{CHOP}$ & $\mathrm{CR}$ & 22 & 28 & $\mathrm{CHOP}$ & PTCL \\
\hline 41 & $\mathrm{CHOP}$ & $\mathrm{CR}$ & 25 & 2 & No treatment & DLBCL \\
\hline 103 & $\mathrm{CHOP}$ & PR & 27 & 32 & R-salvage & DLBCL \\
\hline 32 & $\mathrm{CHOP}$ & Prog & 11 & 6 & Salvage & DLBCL \\
\hline 55 & $\mathrm{CHOP}$ & Prog & 2 & 8 & Salvage & DLBCL \\
\hline 114 & $\mathrm{CHOP}$ & Prog & 15 & 11 & Salvage & DLBCL \\
\hline 24 & $\mathrm{CHOP}$ & Prog & 7 & 13 & Salvage & DLBCL \\
\hline 75 & $\mathrm{CHOP}$ & $\mathrm{CR}$ & 27 & 15 & Salvage & DLBCL \\
\hline 1 & $\mathrm{CHOP}$ & PR & 19 & 16 & Salvage & DLBCL \\
\hline 65 & $\mathrm{CHOP}$ & Prog & 6 & 21 & Salvage & DLBCL \\
\hline 76 & $\mathrm{CHOP}$ & $\mathrm{CR}$ & 63 & 23 & Salvage & DLBCL \\
\hline 51 & $\mathrm{CHOP}$ & PR & 13 & 26 & Salvage & PTCL \\
\hline 16 & $\mathrm{CHOP}$ & $\mathrm{CR}$ & 69 & 35 & Salvage & DLBCL \\
\hline 115 & $\mathrm{CHOP}$ & CR & 33 & 93 & Salvage & PTCL \\
\hline 21 & CHOP & $\mathrm{CR}$ & 90 & 95 & Salvage & DLBCL \\
\hline 14 & CHOP & PR & 237 & 214 & Salvage & DLBCL \\
\hline 84 & CHOP & PR & 39 & 16 & Salvage + asct & DLBCL \\
\hline 111 & CHOP & CR & 41 & 35 & Salvage + asct & DLBCL \\
\hline 106 & CHOP & Prog & 9 & 41 & Salvage + asct & DLBCL \\
\hline 81 & CHOP & $\mathrm{CR}$ & 25 & 102 & Salvage + asct & ALCL \\
\hline 19 & CHOP & $\mathrm{CR}$ & 207 & 134 & Salvage + asct & DLBCL \\
\hline 60 & CHOP & PR & 19 & 32 & Unknown & ALCL \\
\hline 59 & Dose dense & $\mathrm{CR}$ & 41 & 35 & CEOP/IMVP & DLBCL \\
\hline 5 & Dose dense & $\mathrm{CR}$ & 217 & $333+$ & CEOP/IMVP & UNCLASS \\
\hline 13 & Dose dense & $\mathrm{CR}$ & 39 & 40 & CHOP & DLBCL \\
\hline 6 & Dose dense & $\mathrm{CR}+$ & 85 & 220 & CHOP & DLBCL \\
\hline 58 & Dose dense & $\mathrm{CR}$ & 59 & $323+$ & $\mathrm{CHOP}$ & DLBCL \\
\hline 99 & Dose dense & PR & 27 & Lost & Lost & DLBCL \\
\hline 87 & Dose dense & Prog & 9 & 0 & No treatment & DLBCL \\
\hline 88 & Dose dense & PR & 18 & 3 & No treatment & DLBCL \\
\hline 113 & Dose dense & $\mathrm{CR}+$ & 61 & 105 & other & PTCL \\
\hline 67 & Dose dense & CR IF & 213 & $137+$ & R-salvage & DLBCL \\
\hline 56 & Dose dense & $\mathrm{CR}$ & 197 & $192+$ & $\begin{array}{l}\text { R-salvage+ } \\
\text { asct }\end{array}$ & DLBCL \\
\hline 3 & Dose dense & $\mathrm{CR}+$ & 29 & 2 & Salvage & ALCL \\
\hline 104 & Dose dense & PR & 21 & 8 & Salvage & DLBCL \\
\hline 27 & Dose dense & $\mathrm{CR}$ & 24 & 10 & Salvage & DLBCL \\
\hline 35 & Dose dense & PR & 24 & 15 & Salvage & DLBCL \\
\hline 91 & Dose dense & $\mathrm{CR}$ & 29 & 40 & Salvage & DLBCL \\
\hline 71 & Dose dense & PR & 19 & 50 & Salvage & DLBCL \\
\hline 100 & Dose dense & $\mathrm{CR}$ & 91 & $188+$ & Salvage & DLBCL \\
\hline 112 & Dose dense & Prog & 11 & $211+$ & Salvage + asct & DLBCL \\
\hline
\end{tabular}

$R$ rituximab, salvage salvage chemotherapy other than CEOP/IMVP, asct autologous stem-cell transplantation, $D L B C L$ diffuse large B cell lymphoma, $P B$ plasmablastic lymphoma, $A L C L$ anaplastic large-cell lymphoma, $P T C L$ peripheral T cell lymphoma 
rituximab-containing salvage therapy, and five patients had autologous stem-cell transplants (Table 4).

\section{Discussion}

In this randomized, multicenter trial, we tested whether dose-dense therapy improved survival over standard treatment with CHOP. We demonstrated that dose-dense therapy significantly improved the absolute survival by $30 \%$ after 3 years and $34 \%$ after 5 years (Fig. 3). Although survival is the most stable endpoint in clinical trials, some of our findings did not fit into the primary endpoint. The difference in the rate of remission and progression during therapy did not reach a statistically significant level. At the first glance, it is unclear how a better survival could be achieved without a difference in remissions. In the dosedense arm, only three of six PRs relapsed. In the CHOP arm, all seven PRs relapsed (Table 4). The remissions were determined by CT scans, as PET scans were not generally available at the time of the study. Hence, we assume that the CR rate is misleading, and some of the PRs in the dosedense arm were CRs. None of the two progressing patients died in the dose-dense arm, while all seven progressive patients died in the CHOP arm. TTF was better for the dose-dense arm, although this difference did not quite reach statistical significance. Stem-cell transplantation or ritux- imab therapy, which are considered the most effective salvage treatments, do not explain this discrepancy since they were done in such low frequency (Table 4). The more likely explanation for the bigger difference in overall survival compared with TTF is that dose-dense therapy eradicates the most aggressive clones early on and relapses are easier to treat after dose-dense treatment. Unfortunately, we are not able to prove this assumption. However, from the patients' view, survival is the most important result; survival is the most reliable endpoint from the biostatisticians' view as well.

The sample size was thoroughly calculated to verify the difference between dose-dense and CHOP therapy, but it is small relative to other clinical trials. We tested CEOP/IMVP-Dexa in two previous AGMT trials (NHL-1 and NHL-3). The 3-year survivals in these trials were 0.7212 and 0.7610 , respectively. These results support reproducibility of the 3-year survival of 0.766 in the recent trial. The survival in the CHOP arm is comparable with those in other trials (Table 5). However, in the German trial comparing CHOP14 with CHOP21, similar survival results were reported for the CHOP21 arm, despite an older population [22], However, although the patients in our trial are positively selected regarding the age and IPI, comparisons between different trials must be interpreted with great caution because of unrecognized biases.

Table 5 Randomized trials with dose-dense regimens compared to CHOP

\begin{tabular}{|c|c|c|c|c|}
\hline Author & Inclusion & Regimen & 5-year EFS (\%) & 5 -year OS (\%) \\
\hline \multirow[t]{2}{*}{ Pfreundschuh [23] } & $<60 \mathrm{a}$, IPI 0 or 1 & CHOP14/21 & 58 & 80 \\
\hline & & CHOEP14/21 & 69 & 84 \\
\hline \multirow[t]{2}{*}{ Reyes [24] } & $<60 \mathrm{a}$, IPI 0 & CHOP & 74 & 81 \\
\hline & & ACVBP & 82 & 90 \\
\hline \multirow[t]{2}{*}{ Carde [3] } & $<70 \mathrm{a}$, St III or IV & CHOP & 26 & 28 \\
\hline & & CHVmP-VB & 43 & 48 \\
\hline \multirow[t]{2}{*}{ Tilly [25] } & 60-69a, aaIPI $>0$ & CHOP & 29 & 39 \\
\hline & & ACVBP & 39 & 46 \\
\hline \multirow[t]{2}{*}{ Pfreundschuh [22] } & $>60 \mathrm{a}$ & CHOP21 & 33 & 41 \\
\hline & & CHOP14 & 44 & 53 \\
\hline \multirow[t]{2}{*}{ Milpied [19] } & $<60 \mathrm{a}$, aaIPI 1 or 2 & CHOP & 37 & 56 \\
\hline & & CEEP+HDT & 55 & 71 \\
\hline \multirow[t]{2}{*}{ Linch [18] } & $<60 \mathrm{a}$ & CHOP & 50 & 47 \\
\hline & & PACEBOMB & 60 & 56 \\
\hline \multirow[t]{2}{*}{ Fridrik (NHL-5) } & $<71 \mathrm{a}$ & $\mathrm{CHOP}$ & 41 & 40 \\
\hline & & CEOP/IMVP & 55 & 70 \\
\hline
\end{tabular}

$I P I$ international prognostic index, aaIPI age adjusted international prognostic index, EFS event-free survival, $C H O P$ cyclophosphamide, doxorubicin, vincristine, prednisolone, $C H O E P$ cyclophosphamide, doxorubicin, vincristine, etoposide, prednisolone, $A C V B P$ doxorubicin, cyclophosphamide, vindesine, bleomycin, prednisolone, $C H V m P-V B$ cyclophosphamide, doxorubicin, VM-26, prednisolone, vincristine, bleomycin, CEEP cyclophosphamide, epirubicine, vindesine, prednisolone, HDT high-dose therapy, CEOP/IMVP cyclophosphamide, epirubicine, vincristine, prednisolone, ifosfamide, methotrexate, etoposide, $P A C E B O M B$ prednisolone, doxorubicin, cyclophosphamide, etoposide, bleomycin, vincristine, methotrexate 
Another concern might be that the dose-dense regimen is an over treatment for low-risk patients. Subgroup analysis in trials with small patient numbers is always problematic. However, patients with low or low-intermediate IPI have a survival benefit with dose-dense therapy (Fig. 5).

A key question is whether patients in the dose-dense arm actually received more dose density than patients in the CHOP arm. The planned dose intensity was higher in the dose-dense arm than in the CHOP arm (Table 2). In addition, ifosfamide, etoposide, and methotrexate were given. On the other hand, dose reductions were more frequent in the dosedense arm. For patients over the age of 60 , a $20 \%$ dose reduction was mandatory. However, $45 \%$ of cycles of the dose-dense therapy were delayed for not more than 1 day, and in $85 \%$ of cycles, the therapy intervals were shorter than 3 weeks. Dose was adjusted to toxicity. Patients without toxicity received the full dose. In other patients, the dose was reduced to a tolerable level. Thus all patients received the highest tolerable dose density.

Toxicity is one of the major concerns in chemotherapy treatment regimens. Not surprisingly, the dose-dense arm had significantly higher toxicity (Table 3). However, most side effects subsided within a few weeks. Only neurotoxicity persisted up to 3 months after the dose-dense therapy. Myelodysplasia or leukemia was not observed. Treatmentrelated deaths were less frequent in the dose-dense arm. Apart from toxicity, dose-dense therapy is more cumbersome to apply, has higher costs, and requires more hospital or outpatients visits than CHOP. Considering the survival benefit of the dose-dense therapy, these disadvantages should be acceptable.

Other researchers have also shown that dose-dense regimens are more effective than CHOP. The superiority of ACVBP, a dose-dense regimen, was demonstrated for patients from 61 to 69 years of age 25 and at the least one adverse prognostic factor and for younger patients in stage I or II [24]. A British Group used PACEBOME in a dosedense manner and had a superior cause-specific survival than CHOP [18]. Finally, bi-weekly CHOP showed better survival in an elderly population in a German trial [22]. In none of these trials did the difference with standard CHOP reach a level of $34 \%$ as it did in our study (Table 5). In a patient population similar to the population in our study, a 2 -year overall survival of $67 \%$ was achieved with VACOP$\mathrm{B}$ [2], a dose-dense regimen. However, VACOP-B has not been compared with $\mathrm{CHOP}$ in a randomized trial.

High-dose therapy with autologous stem-cell rescue was another promising attempt to overcome resistance and improve treatment outcome for aggressive non-Hodgkin's lymphoma. The results of this attempt were conflicting, and a recent comprehensive review of high-dose therapy in first-line treatment of aggressive non-Hodgkin's lymphoma failed to find an improvement [14]. The toxicity of high- dose therapy prohibits subsequent cytotoxic therapy for a longer time period. If the high-dose therapy did not eradicate the last lymphoma cell, rapid regrowth of the lymphoma would take place, according to the Gompertzian model [20].

Rituximab $(\mathrm{R})$ has considerably changed the treatment of B cell lymphoma [5, 15, 21, 23], but it was not available until after the recruitment for our study was completed. Chemotherapy without rituximab is no longer the standard treatment for diffuse large-cell lymphoma. Now, it is more important to determine if dose-dense therapy can improve on R-CHOP. The GELA Group is currently completing a randomized trial (LNH 03-6B) comparing $\mathrm{R}-\mathrm{CHOP} 21$ to $\mathrm{R}-\mathrm{CHOP} 14$. The results are eagerly awaited. The RICOVER60 trial could show that rituximab, when added to CHOP14, results in a better outcome [21]. We recently finished a phase II trial with dose-dense therapy and rituximab $375 \mathrm{mg} / \mathrm{m}^{2}$ on days 1 and 15 . Comparing these patients with the patients in this NHL-5 trial, we observed a significant TTF and OS benefit of R-CEOP/IMVP compared to CHOP. R-CEOP/IMVP also results in a better, but to date, not statistically significant TTF and OS compared to the dose-dense arm in NHL-5. If we will find a statistically significant difference with longer follow-up, we will conduct a randomized trial comparing $\mathrm{R}-\mathrm{CHOP}$ with R-CEOP/IMVP. Until proven otherwise, R-CHOP still remains the standard.

Acknowledgments The study was supported by the Austrian social insurance company "Hauptverband österreichischer Sozialversicherungsträger". This company provided the drugs used in the study.

\section{References}

1. The International Non-Hodgkin's Lymphoma Prognostic Factors Project (1993) A predictive model for aggressive non-Hodgkin's lymphoma. N Engl J Med 329:987-994. doi:10.1056/ NEJM199309303291402

2. Bertini M, Freilone R, Botto B, Calvi R, Gallamini A, Gatti AM, Liberati AM, Meneghini V, Orlandi E, Orsucci L, Pizzuti M, Scalabrini DR, Salvi F, Todeschini G, Vitolo U, Resegotti L (1997) Idarubicin in patients with diffuse large cell lymphomas: a randomized trial comparing VACOP-B ( $\mathrm{A}=$ doxorubicin) vs VICOP-B (I=idarubicin). Haematologica 82:309-313

3. Carde P, Meerwaldt JH, van Glabbeke M, Somers R, Monconduit M, Thomas J, de Wolf-Peeters C, de Pauw B, Tanguy A, KluinNelemans JC, Noordijk EM, Regnier R, Bron D, LustinanMarechal J, Caillou B, Bosq J, van Heerde P, van Unnik JAM, Burgers JMV, Hayat M, Cosset JM, Evd S, Wagener J, Hagenbeek A, Cattan A, Duez N, Tubiana M, on behalf of the ELG (1991) Superiority of second over first generation chemotherapy in a randomized trial for stage III-IV intermediate and high-grade NonHodgkin's Lymphoma (NHL): The 1980-1985 EORTC trial|*. Ann Oncol 2:431-435

4. Cheson BD, Horning SJ, Coiffier B, Shipp MA, Fisher RI, Connors JM, Lister TA, Vose J, Grillo-Lopez A, Hagenbeek A, Cabanillas F, Klippensten D, Hiddemann W, Castellino R, Harris 
NL, Armitage JO, Carter W, Hoppe R, Canellos GP (1999) Report of an International Workshop to Standardize Response Criteria for Non-Hodgkin's Lymphomas. J Clin Oncol 17:1244

5. Coiffier B, Lepage E, Briere J, Herbrecht R, Tilly H, Bouabdallah R, Morel P, Van Den Neste E, Salles G, Gaulard P, Reyes F, Lederlin P, Gisselbrecht C (2002) CHOP chemotherapy plus rituximab compared with $\mathrm{CHOP}$ alone in elderly patients with diffuse large-B-cell lymphoma. N Engl J Med 346:235-242. doi:10.1056/NEJMoa011795

6. Cox DL (1972) Regression models an life tables. J Roy Statist Soc Ser B Methodological 34:187

7. DeVita VT Jr, Canellos GP, Chabner B, Schein P, Hubbard SP, Young RC (1975) Advanced diffuse histiocytic lymphoma, a potentially curable disease. Lancet 1:248-250. doi:10.1016/ S0140-6736(75)91142-3

8. Fisher RI, Gaynor ER, Dahlberg S, Oken MM, Grogan TM, Mize EM, Glick JH, Coltman CA Jr, Miller TP (1993) Comparison of a standard regimen (CHOP) with three intensive chemotherapy regimens for advanced non-Hodgkin's lymphoma. N Engl J Med 328:1002-1006. doi:10.1056/NEJM199304083281404

9. Fisher RI, Miller TP, Dana BW, Jones SE, Dahlberg S, Coltman CA Jr (1987) Southwest oncology group clinical trials for intermediate- and high-grade non-Hodgkin's lymphomas. Semin Hematol 24:21-25

10. Fridrik MA, Greil R, Hausmaninger H, Krieger O, Oppitz P, Stoger M, Klocker J, Neubauer M, Helm W, Pont J, Fazeny B, Hudec M, Simonitsch I, Radaszkiewicz T (1997) Randomized open label phase III trial of CEOP/IMVP-Dexa alternating chemotherapy and filgrastim versus CEOP/IMVP-Dexa alternating chemotherapy for aggressive non-Hodgkin's lymphoma (NHL). A multicenter trial by the Austrian Working Group for Medical Tumor Therapy Ann Hematol 75:135-140

11. Fridrik MA, Hausmaninger H, Linkesch W, Greil R, Krieger O, Baldinger C, Klocker J, Pont J, Oberaigner W (2005) Long-term results of dose density therapy in patients with aggressive lymphoma. Ann Hematol 84:217-222. doi:10.1007/s00277-0040936-x

12. Fridrik MA, Hausmaninger H, Linkesch W, Stoger M, Sill H, Neubauer M, Seewann HL, Klocker J, Haidinger R, Schiller L, Pont J, Raudaschl G, Falk M, Radaszkiewicz T (1996) CEOPIMVP-Dexa in the treatment of aggressive lymphomas: an Austrian multicenter trial. J Clin Oncol 14:227-232

13. Goldie JH, Coldman AJ, Ng V, Hopkins HA, Looney WB (1988) A mathematical and computer-based model of alternating chemotherapy and radiation therapy in experimental neoplasms. Antibiot Chemother 41:11-20

14. Greb A, Bohlius J, Trelle S, Schiefer D, De Souza CA, Gisselbrecht C, Intragumtornchai T, Kaiser U, Kluin-Nelemans HC, Martelli M, Milpied NJ, Santini G, Verdonck LF, Vitolo U, Schwarzer G, Engert A (2007) High-dose chemotherapy with autologous stem cell support in first-line treatment of aggressive non-Hodgkin lymphoma-results of a comprehensive metaanalysis. Cancer Treat Rev 33:338-346. doi:10.1016/j. ctrv.2007.02.002

15. Habermann TM, Weller EA, Morrison VA, Gascoyne RD, Cassileth PA, Cohn JB, Dakhil SR, Woda B, Fisher RI, Peterson BA, Horning SJ (2006) Rituximab-CHOP versus CHOP alone or with maintenance rituximab in older patients with diffuse large bcell lymphoma. J Clin Oncol 24:3121-3127
16. Kaplan E, Meier P (1958) Nonparametric estimation from incomplete observations. J Am Stat Assoc 53:547-581. doi: $10.2307 / 2281868$

17. Kimby E, Brandt L, Nygren P, Glimelius B (2001) A systematic overview of chemotherapy effects in aggressive non-Hodgkin's lymphoma. Acta Oncol 40:198-212. doi:10.1080/ 02841860151116268

18. Linch DC, Smith P, Hancock BW, Hoskin PJ, Cunningham DC, Newland AC, Milligan D, Stevenson PA, Wood JK, Maclennan KA, Vaughan B, Vaughan G, Gregory WM (2000) A randomized British National Lymphoma Investigation trial of CHOP vs. a weekly multi-agent regimen (PACEBOM) in patients with histologically aggressive non-Hodgkin's lymphoma. Ann Oncol 11(Suppl 1):87-90. doi:10.1023/A:1008381811131

19. Milpied N, Deconinck E, Gaillard F, Delwail V, Foussard C, Berthou C, Gressin R, Lucas V, Colombat P, Harousseau J-L, the Groupe Ouest-Est des Leucemies et des Autres Maladies du S (2004) Initial treatment of aggressive lymphoma with high-dose chemotherapy and autologous stem-cell support. N Engl J Med 350:1287-1295. doi:10.1056/NEJMoa031770

20. Norton L, Simon R (1977) Growth curve of an experimental solid tumor following radiotherapy. J Natl Cancer Inst 58:1735-1741

21. Pfreundschuh M, Schubert J, Ziepert M, Schmits R, Mohren M, Lengfelder E, Reiser M, Nickenig C, Clemens M, Peter N, Bokemeyer C, Eimermacher H, Ho A, Hoffmann M, Mertelsmann R, Trumper L, Balleisen L, Liersch R, Metzner B, Hartmann F, Glass B, Poeschel V, Schmitz N, Ruebe C, Feller AC, Loeffler M (2008) Six versus eight cycles of bi-weekly CHOP-14 with or without rituximab in elderly patients with aggressive CD20+ Bcell lymphomas: a randomised controlled trial (RICOVER-60). Lancet Oncol 9:105-116. doi:10.1016/S1470-2045(08)70002-0

22. Pfreundschuh M, Trumper L, Kloess M, Schmits R, Feller AC, Rube C, Rudolph C, Reiser M, Hossfeld DK, Eimermacher H, Hasenclever D, Schmitz N, Loeffler M, German High-Grade NonHodgkin's Lymphoma Study G (2004) Two-weekly or 3-weekly CHOP chemotherapy with or without etoposide for the treatment of elderly patients with aggressive lymphomas: results of the NHL-B2 trial of the DSHNHL. Blood 104:634-641

23. Pfreundschuh M, Trumper L, Osterborg A, Pettengell R, Trneny M, Imrie K, Ma D, Gill D, Walewski J, Zinzani PL, Stahel R, Kvaloy S, Shpilberg O, Jaeger U, Hansen M, Lehtinen T, LopezGuillermo A, Corrado C, Scheliga A, Milpied N, Mendila M, Rashford M, Kuhnt E, Loeffler M (2006) CHOP-like chemotherapy plus rituximab versus CHOP-like chemotherapy alone in young patients with good-prognosis diffuse large-B-cell lymphoma: a randomised controlled trial by the MabThera International Trial (MInT). Group Lancet Oncol 7:379-391. doi:10.1016/ S1470-2045(06)70664-7

24. Reyes F, Lepage E, Ganem G, Molina TJ, Brice P, Coiffier B, Morel P, Ferme C, Bosly A, Lederlin P, Laurent G, Tilly H (2005) ACVBP versus $C H O P$ plus radiotherapy for localized aggressive lymphoma. N Engl J Med 352:1197-1205. doi:10.1056/ NEJMoa042040

25. Tilly H, Lepage E, Coiffier B, Blanc M, Herbrecht R, Bosly A, Attal M, Fillet G, Guettier C, Molina TJ, Gisselbrecht C, Reyes F (2003) Intensive conventional chemotherapy (ACVBP regimen) compared with standard CHOP for poor-prognosis aggressive non-Hodgkin lymphoma. Blood 102:4284-4289. doi:10.1182/ blood-2003-02-0542 